\title{
O MITO DO ELDORADO AMAZÔNICO DESMONTADO EM A SELVA DE FERREIRA DE CASTRO
}

\author{
Ivanete da Silva Alves \\ Mestranda em Estudos Literários pela UFMG \\ ivanety_23@hotmail.com
}

\section{RESUMO}

A perspectiva do Eldorado foi bastante projetada na Amazônia. Isso se iniciou ainda nos primeiros contatos por viajantes e conquistadores. Mitos em torno da região davam conta de que ela era fonte de prosperidade. No entanto, tais discursos foram desmontados ao se presenciar a realidade dos sujeitos no referido espaço. Diante da notável constatação, refletir sobre a desconstrução da ideia de "Amazônia paradisíaca" é o propósito da pesquisa em questão que será feita por meio da análise do romance $A$ selva (1930), do escritor português José Maria Ferreira de Castro. A reflexão proposta terá auxílio de teóricos como Pizarro (2012); Souza (1977); Weinstein (1993).

Palavras-chave: Amazônia; imagens; mito; Ferreira de Castro.

\begin{abstract}
RESUMEN
La perspectiva de Eldorado fue bastante proyectadaenlaAmazonia.

Estoempezóenlosprimeroscontactos por viajeros y conquistadores. Mitos alrededor de ese lugar se dabancuenta de que él era sinónimo de prosperidad. Sin embargo, estos discursos fueron desmontados al presenciar larealidadeneseespacio. Por eso, reflexionar sobre ladeconstrucción de esa mirada hacialaAmazonia es el propósito de este trabajo que se hará por mediodelanálisis de la novela La selva, de Ferreira de Castro. La reflexiónpropuestatendráayuda de teóricos como, Pizarro (2012); Souza; (1977); Weinstein (1993).
\end{abstract}

Palabras clave: Amazonia; imágenes; mito; Ferreira de Castro.

\section{INTRODUÇÃO}

Muitas imagens da Amazônia circulam desde o início da ocupação europeia no século XVI. Uma das figurações é a que gira em torno da ideia de riqueza. Diversas crônicas de viajantes naturalistas e outras narrativas contribuíram para difundir essa representação. No entanto, há questionamentos a respeito de tal compreensão. Diante da visível problemática, 
intenta-se neste trabalho tecer uma reflexão sobre a perspectiva de riqueza voltada à Amazônia. O estudo em questão pretende alargar o debate sobre a percepção da região e contribuir com a fortuna crítica.

É notório que a Amazônia, formada por grandiosa floresta e imensos rios, foi amplamente vista de forma binária: às vezes como paraíso, outras como lugar de tormentos. Bárbara Weinstein afirma a percepção dúbia: “os primeiros exploradores divulgaram a região ora como paraíso tropical, ora como inferno verde" (WEINSTEIN, 1993, p. 21). Isso porque "a extraordinária vastidão da Amazônia tem inspirado aos seus invasores fascinação e pavor a um só tempo" (WEINSTEIN, 1993: 21).

Tal compreensão motivou várias expedições em busca de tesouros na região. Muitos escritos, como diários de viajantes e até mesmo obras literárias dão, conta da imagem de Eldorado do espaço amazônico. A viagem de Francisco de Orellana e Gonzalo Pizarro, no século XVI, exemplifica a ideia levantada. É conhecido que os dois exploradores percorreram os grandes caminhos hídricos da selva em busca do mítico lugar chamado País da Canela. No entanto, posteriormente, "a procura do País da Canela já se transformou na busca do Eldorado" (PIZARRO, 2012, p. 43).

O mito da fonte de riqueza foi amplamente projetado na Amazônia. Pizarro afirma que essa ideia "é a concretização do desejo de enriquecimento do europeu na América" (PIZARRO, 2012, p. 79). A teórica também menciona que "o mito do Eldorado é um dos mais populares da época na América, atravessando os séculos até os dias de hoje, pois ainda há expedições de aventureiros que percorrem os espaços amazônicos em busca de Paititi ou de Namoa" (PIZARRO, 2012, p. 79). 
Assim, a região, desde o começo de sua ocupação pelos europeus, foi vista como sinônimo de fortuna em decorrência de "seus recursos imensos reais e imaginários" (Gonçalves, 2005, p. 25). Barbara Weinstein focaliza tal pensamento ao deixar claro que "a grande variedade de recursos disponíveis na Amazônia provocava excessivos louvores dos visitantes" (WEINSTEIN, 1993, p. 29).

Um dos momentos de grande expectativa de enriquecimento focalizado na região foi o período de expansão da borracha (1850-1920). No contexto em questão, a Amazônia era a única fornecedora de látex no mundo. Tal fato levou à procura da selva por pessoas de diversas partes, como Europa, Oriente e Oriente Médio e de diferentes regiões brasileiras, ao exemplo de nordestinos que intuíam melhorias financeiras. Lima discorre sobre o cenário pontuado e menciona que "os preços em alta da borracha no mercado internacional atraíram uma corrida à extração do ouro negro" (LIMA, 2009, p. 29).

Os sertanejos eram abordados em sua terra natal por agentes, conhecidos como aviadores, a serviço dos seringalistas. Sabe-se que "a casa aviadora que providenciava o transporte e a distribuição dos retirantes que fugiam da seca do Nordeste para trabalhar nos seringais" (WEINSTEIN, 1993, p. 34). Os aviadores usavam discursos de que a Amazônia garantia a prosperidade e, assim, convenciam os indivíduos a tornarem-se seringueiros.

Movidos pelo sonho do êxito financeiro, "os nordestinos chegaram em grandes levas à Amazônia" (LIMA, 2009, p. 40), principalmente, porque, no referido momento, o sertão nordestino passava por um intenso período de seca. Pizarro fala sobre a necessidade e o propósito desses homens: "os que viajavam à Amazônia eram movidos pelo desespero da luta contra a subsistência e com a expectativa de voltar com dinheiro para alimentar suas famílias" (PIZARRO, 2012, p. 116). 
É esse contexto que o romance $A$ selva, de José Maria Ferreira de Castro, retrata. A obra castriana denuncia a rede de exploração que prendeu os coletores de borracha nos seringais amazônicos no final do século XIX e início do XX. Márcio Souza diz que "Ferreira de Castro, com A selva, resumiu os trinta anos de loucuras nos seringais" (SOUZA, 1977, p. 123). O romancista mostrou ao mundo a história de homens oprimidos pela natureza e envoltos a um sistema semiescravista. Nessa empreitada, ele "dá conta de uma realidade que em si clama por justiça" (CRISTÓVÃO, 1974, p. 21).

\section{O CONTEXTO DE PRODUÇÃO DE A SELVA}

A selva é fruto da experiência pessoal de Ferreira de Castro na Amazônia brasileira. Ele chegou à região com doze anos no início de 1911. O escritor afirmou a data da chegada quando escreveu sobre a viagem que fez ao Rio de Janeiro, em 1959, a convite da União Brasileira de Escritores. "Quinze dias depois, feitas as escalas de Lisboa e S. Vicente, desembarquei pela primeira vez no Brasil, em Belém do Pará, a 22 de Janeiro de 1911, sem saber onde pôr os braços e onde pousar os olhos diante das pessoas grandes - e muito menos qual seria o meu destino" (CASTRO, 2007, p. 16).

O português pertencia a uma família pobre e era órfão de pai. Ele direcionou-se ao Norte brasileiro almejando prosperidade, como tantos outros. Contudo, ao invés de fortuna, só encontrou opressão e mazelas. Foram quatro anos vividos no seringal e o escritor lusitano jamais negou o sofrimento vivido e presenciado na Amazônia. "Tremendas horas suportei no Brasil: primeiro no mundo elementar da floresta virgem, mais tarde em Belém do Pará, cromática, luminosa cidade, que uma vez projectada através dos nossos olhos, fica a residir, 
para sempre, na memória" (CASTRO, 2007, p.23). Assim, "experimentou ele mesmo, o destino de ser personagem" (SOUZA, 1977, p. 123).

O cenário de degradação humana resultou em $A$ selva. O autor nunca escondeu a relação do surgimento dessa narrativa com os anos difíceis que passou na região amazônica. O sentimento de Ferreira de Castro fica nítido no texto que antecede a obra. "Havia em mim o desejo de dar uma síntese de toda a selva do Amazonas e, não só por isso, mas pela força da própria experiência pessoal" (CASTRO, 1972, p. 30).

A obra enfoca o período da extração da borracha no Norte brasileiro. Ela narra a estada na Amazônia do lusitano Alberto, jovem de vinte e seis anos que se ausentou de Portugal por causa de conflitos políticos. No seu país, o protagonista viveu momentos tensos com o governo, uma vez que Portugal passava por uma instabilidade política, já que ideologias monarcas e republicanas estavam em fortes embates. 0 personagem central era monárquico e lutou em prol da continuação desse governo. Mas os atos da revolução republicana estavam cada vez mais fortes. Então, evitando a morte, ele fugiu para a Espanha e, posteriormente, dirigiu-se ao Brasil.

Alberto chegou a Belém para morar na casa de um tio. No entanto, o parente o considerava um peso porque o rapaz não conseguia emprego. Diante disso, convenceu o sobrinho a trabalhar no seringal Paraíso (propriedade de Juca Tristão) no Rio Madeira, no Amazonas. O protagonista viajou com vários nordestinos, os quais deixaram os lugares de origem esperançosos por melhorias financeiras. Durante quinze dias eles ocuparam a terceira classe do barco Justo Chermont.

Quando chegaram ao seringal, foram dirigidos às colocações (local de trabalho). Alberto foi para a Todos os Santos na companhia do experiente seringueiro Firmino. Lá, 
trabalhou no corte da seringa, viveu a difícil realidade de todos os quais se encontravam aprisionados tanto pela selva quanto pelo patrão. Depois de certo tempo, o seringalista o tirou do corte da seringa e o colocou na função de auxiliar de guarda-livros. O trabalho contábil levou o personagem central a perceber toda a discrepância financeira naquele ambiente. Ele foi o único que conseguia permissão do patrão para deixar o lugar. No entanto, antes de regressar, o ex-escravo, Tiago, incendiou a casa do seringalista, matando0 .

Segundo Cristóvão (1974, p. 21), A selva é um romance "social e de característica popular". Francisca Amélia da Silveira diz que ele pode ser dividido em três partes: "a viagem de Belém ao rio Madeira, a experiência de Alberto como seringueiro e, finalmente, sua transferência do seringal para o barracão à beira do rio, onde passa a trabalhar como auxiliar de guarda-livros" (SILVEIRA, 2001, p. 55).

O texto, publicado pela primeira vez em 1930, é dividido em quinze capítulos e tem um narrador externo à trama, que possui largo conhecimento sobre toda a história e conhece a trajetória, os sentimentos e os pensamentos mais íntimos dos personagens. narrador, no entanto, descreve os eventos a partir do ponto de vista do protagonista, embora em alguns momentos focalize outros personagens, como Firmino: "amigo mais próximo de Alberto, espécie de protetor humilde do doutorzinho desajeitado, ele é o esfacelamento vivo do homem naquela situação absurda" (SOUZA, 1977, p. 126). Portanto, a região amazônica é representada no romance por meio de uma perspectiva estrangeira.

Essa percepção por um olhar externo é acompanhada pelo leitor, que observa e compreende o enredo e o espaço na medida em que o português vivencia a Amazônia e suas experiências vão sendo efetivadas. Cada etapa da trajetória do lusitano naquele meio é uma 
descoberta para ele e também para o leitor. Como a viagem de Belém ao seringal, na qual Alberto se surpreende com a grandiosidade da paisagem natural; o trabalho na coleta da borracha, primeiramente na condição de "brabo" (novatos no seringal), depois como veterano; e a ida para o barracão, quando o protagonista entra em contato com a contabilidade de Juca Tristão, "peça importante dum sistema de opressão que vive do trabalho escravo nas estradas nas estradas de seringas e nas manobras sórdidas do comercio do barracão" (CRISTÓVÃO, 1974, p. 21). Desse modo, o universo amazônico é desvendado, simultaneamente, tanto pelo personagem quanto pelo leitor.

\section{O ELDORADO AMAZÔNICO}

A obra castriana aponta para a perspectiva do Eldorado na Amazônia. Ela mostra a realidade de indivíduos que se dirigiam à região acreditando que conseguiriam riqueza com a coleta do látex. Essa percepção é explícita pela narração "era, então, a Amazônia um imã na terra brasileira e para ela convergiam copiosas ambições dos quatro pontos cardeais, porque a riqueza se apresentava de fácil posse" (CASTRO, 1972, p. 41). O diálogo entre o protagonista Alberto e seu tio também revela isso:

E não te aborreças, pois aquilo, para quem tem sorte e juízo, são terras onde se enriquece em pouco tempo. [...] Fora assim que seu tio enriqueceu tinha já duas quintas em Portugal; fora assim que pobretões sem eira nem beira se transformaram, dum instante para outro, em donos de casas aviadoras, tão poderosas que sustentavam no dédalo fluvial grande frota de gaiolas. [...] Olha que eu tenho visto muito homem embarcar nas tuas condições e voltar, lá em cima, podre de rico (CASTRO, 1972, p. 40- 41; 51).

O pensamento do tio de Alberto é o mesmo dos novatos seringueiros. A fala do experiente seringueiro Firmino evidencia isso: "Quando seu Alípio foi ao Ceará buscar o 
pessoal, me disse que um homem enriquecia logo que chegava aqui" (CASTRO, 1972, p. 123). Os sertanejos, iludidos pela promessa de enriquecimento. seguiam em longas viagens almejando vida melhor. No entanto, a distância não consistia em empecilhos aos nordestinos porque eles idealizavam suas vidas no futuro glorioso que os aguardavam na Amazônia. Assim, o deslocamento não tinha tanta relevância, uma vez que era apenas uma etapa para se chegar ao objetivo almejado.

Contudo, nota-se que o ideal de enriquecimento na selva começava a se desfazer em pouco tempo após a chegada ao seringal. Os sertanejos não demoravam muito para constatar a situação desumana na qual seriam submetidos durante a estada ali. Todas as promessas acreditadas passavam a ser dúvida, já que "chegando ao seringal, a realidade para os migrantes era bem diferente" (GUILLEN, 2006, p. 114).

\section{DA ÓTICA DO ELDORADO AO INFERNO}

Na Amazônia, as dificuldades impostas aos retirantes começavam com o medo dos indígenas. Isso fica claro no diálogo entre o veterano Firmino e Alberto: “A estrada que você vai cortar era do Feliciano. O mês passado, os índios vieram e levaram a cabeça dele. É por isso que a estrada está sem freguês e você vai pra ela" (CASTRO, 1972, p. 105).

A hostilidade aos estrangeiros também é causada pela própria floresta. A ação da selva é mostrada pelo narrador a partir do estranhamento do olhar de Alberto, o qual percebe a natureza como perigosa e traiçoeira porque compreende que às vezes ela aparenta exuberância para fascinar e encantar os novos habitantes tanto pela beleza quanto pela raridade, no entanto, de imediato, ela se revela em um ser perverso que aprisiona, limita e destrói a vida humana: 
Estendeu o braço e apanhou a flor. Quanto valeria aquilo em Portugal! E a mata estava cheinha delas! Eram orquídeas preciosas, de recorte singular e cores surpreendentes cataleas de pétalas tersas de lírio que tinham algo de sexo virgem e fascinavam como uma ilusão [...] A ameaça andava no ar que se respirava, na terra que se pisava, na água que se bebia, porque ali somente a selva tinha vontade e imperava despoticamente. Os homens eram títeres manejados por aquela força oculta, que se julgavam, ilusoriamente, ter vencido com a sua atividade, o seu sacrifício e a sua ambição. [...] Alí não existia mesmo a árvore. Existia o emaranhado vegetal, louco, desorientado, voraz, com alma e garras de fera esfomeada. Estava de sentinela, silencioso, encapotado, a vedar-lhe todos os passos, a fechar-lhe todos os caminhos, a subjuga-lo no cativeiro (CASTRO, 1972, p. $170 ; 180)$.

Em toda a narrativa, a floresta ganha realce de personagem relevante pelas ações maléficas. "Vista por dentro, oprimia e fazia anelar a morte. Só a luz obrigava o monstro a mudar de fisionomia, revelando as suas pesadas atitudes, mas persistindo sempre no seu ar enigmático" (CASTRO, 1972, p. 115).

A própria quietude da natureza causava pânico aos retirantes: "Mas o silêncio volvia. E com ele uma longa, uma indecifrável expectativa. Dir-se-ia que a selva, como uma fera, aguardava há muitos milhares de anos a chegada de maravilhosa e incognoscível presa" (CASTRO, 1972, p. 104). Assim, a floresta configura-se como suprema, uma vez que impera sobre o homem, tornando-o impotente diante de tanta grandeza:

A selva dominava tudo. Não era o segundo reino, eram o primeiro em força e categoria, tudo abandonado a um plano secundário. E o homem, simples transeunte no flanco do enigma, via-se obrigado a entregar o seu destino àquele despotismo. Dir-se-ia que a selva tinha, como monstros fabulosos, mil olhos ameaçadores, que espiavam de todos os lados. Nada a assemelhava às últimas florestas do Velho Mundo" (CASTRO, 1972, p. 115). 
Tal compreensão sobre a floresta amazônica foi construída ainda nas primeiras expedições realizadas pelos povos ibéricos. Isso é pontuado pelo texto de Ferreira de Castro ao se referir a acontecimentos que ocorreram nas primeiras ações de ocupação. Ele cita as aventuras de alguns viajantes, como João de Barros Guerra e Francisco de Mello Palheta ${ }^{1}$, e não hesita em averbar que no período da expedição desses homens "a selva virgem parecia querer assim castigar aquele que ousava violar o seu mistério" (CASTRO, 1972, p. 85).

Visão similar a da narrativa tem Euclides da Cunha. O autor afirma que o seringueiro "chegou sem ser esperado nem querido, quando a natureza ainda estava arrumando o seu mais vasto e luxuoso salão" (CUNHA, 1999, p. 2). A floresta que parece infinita demonstra o dom de angustiar os novos habitantes pela própria grandeza, como evidencia a narração: “A tristeza brotava desse verde eterno e sempre igual, que oprimia, que sufocava com a sua pertinácia e exuberância" (CASTRO, 1972 p. 187).

Tal compreensão do meio natural, mostrada no texto castriano, é comentada pelo romancista Milton Hatoum. O escritor brasileiro pontua que a floresta "vista de longe, a percepção que o narrador tem do espaço é a de uma grandeza inabarcável, mas também lembra um mostro líquido" (HATOUM, 1993, p. 107).

No espaço amazônico, os coletores de borracha não são "nem perfeitos, nem atletas, são mais que sombra contra um horizonte verde" (SOUZA, 1977, p. 126). Por isso, Pizarro diz que em tal contexto "a força da natureza é um elemento que se luta para sobreviver" (PIZARRO, 2012, p. 57). Essa projeção da selva é visível para Alberto. “O resto era a selva, com a sua vida sombria, ali pertinho, muito pertinho, fechando-o num anel estrangulador.

$1 \quad$ Os dois fizeram expedições no Rio Madeira no século XVIII. 
Sentia-se-lhe a existência pesada, enigmática, numa vigília que dir-se-ia constante ameaça, um pânico jacente" (CASTRO, 1972, 128).

Então, o espaço vai sendo montado pela perspectiva estrangeira evidenciando o "inferno verde". Contudo, a narração amplia o leque e passa a revelar que a brutalidade por parte da floresta existe, mas a maior selvageria vem das relações sociais em decorrência da exploração e ganância que prendiam os trabalhadores por anos no seio vegetal.

A rede exploratória na qual os seringueiros encontravam-se envolvidos começava a ser tecida antes da chegada deles aos seringais, visto que os patrões arcavam com os gastos das viagens (do sertão até a Amazônia), mas os trabalhadores deveriam ressarcir o seringalista com a borracha coletada. Isso consistia no sistema de aviamento, espécie de crédito que, além de financiar o trajeto, custeavam os produtos necessários à subsistência. Assim, "os trabalhadores agenciados chegavam aos seringais com a dívida dos custos da própria viagem, além de ter que pagar os utensílios que utilizavam e os víveres que lhes eram antecipados pelo seringalista" (GONÇALVES, 2005, p. 86).

A dívida contraída com o seringalista era apresentada aos seringueiros antes da ida às colocações (postos de trabalhos). Esse débito configurava-se como uma teia que impossibilitava os trabalhadores de deixar a selva, uma vez que a dívida dava ao patrão “amplos poderes sobre eles, inclusive de caçá-los em fuga e recebê-los de volta com auxílio do poder público" (LIMA, 2009, p. 35). O aprisionamento dos coletores é relatado pelo narrador ao citar o documento que certificava os gastos: "aquele era sempre o talão grande, onde se juntavam as despesas da viagem e mais empréstimos, que prendiam por muitos anos ao seringal, em trabalho de pagamento, o sertanejo ingênuo" (CASTRO, 1972, p. 101). 
Os débitos dificilmente se fechavam porque os donos de seringais agiam em prol de sua infinitude, uma vez que "era a dívida permanente e estrutural do seringueiro que dava sustentação a todo sistema" (GONÇALVES, 2005, p. 87). Os patrões aproveitavam-se da falta de opção dos sertanejos e vendiam todos os produtos por valores superfaturados. "Estavam ali as faturas, vendendo a Juca Tristão por cinco o que ele entregava aos seringueiros por quinze e muitas vezes até por vinte" (CASTRO, 1972, p.112). Desse modo, "para obter lucro num sistema tão instável, lançavam mão de sobretaxas de preços nas mercadorias que repassavam aos seringueiros" (LIMA, 2009, p. 37).

Além do superfaturamento das mercadorias, os seringalistas não valorizavam a produção dos coletores, já que pagavam uma quantia irrelevante pelas borrachas: "estavam as notas da borracha, o que se comprava ali por dois e se vendia por cinco ou seis na praça de Manaus" (CASTRO, 1972, p. 212). Pequeno lucro para o grande trabalho. Pizarro diz que “a obtenção da resina é trabalhosa, especialmente devido ao lugar onde é encontrada, em geral um lugar emaranhado e repleto de perigos na selva" (PIZARRO, 2012, p.114).

Outra estratégia comercial usada pelos seringalistas consistia na proibição dos seringueiros de manterem famílias no seringal, como é perceptível na narração: "Se um homem tivesse família aqui trabalhava menos para o patrão. [...] e seu Juca não quer isso. 0 que seu Juca quer é seringueiro sozinho, que trabalha muito com a ideia de tirar saldo para ir ver a mulher ou casar lá no Ceará" (CASTRO, 1972, p. 131- 140).

Portanto, os coletores viviam privados da própria dignidade humana em decorrência do sistema exploratório e semiescravista que os impossibilitavam de deixar a selva e os obrigavam a trabalhar cada vez mais para liquidar uma dívida, praticamente não liquidável: 
Não há maneira de me livrar daquela conta [...] e, afinal, ainda não paguei a passagem. Eles, assim que nós chegamos, já não dizem mais coisas bonitas. Vendem tudo muito caro, que é para o seringueiro não arranjar saldo e ficar toda a vida nestas brenhas do diabo (CASTRO, 1972, p. 123)

Os coletores de borracha encontram-se suplantados, sem direitos reconhecidos, submersos ao abandono. É por isso que Cunha diz que o seringueiro "é um excomungado pela própria distância que o afasta dos homens; e os grandes olhos de Deus não podem descer até aqueles brejais" (CUNHA, 1999, p. 53).

Com todas as explorações sofridas, os nordestinos perdiam as expectativas que lhes conduziram à floresta. "O regresso à aldeia nativa, lá longe, no sertão do Ceará ou do Maranhão, passara de certeza a dúvida e de dúvida a incredulidade" (Castro 1972, p.95). Tudo porque, "a realidade encontrada estava longe daquela com a qual tinham sonhado, pois viviam uma semiescravidão, em que a possibilidade de regressar não figurava no horizonte" (PIZARRO, 2012, p.116).

No contexto, os benefícios financeiros decorrentes do comércio da borracha eram concedidos apenas aos patrões. O protagonista pensa sobre isso após o exercício da função contábil no barracão: “Alberto, que reflete a situação desumana dos seringueiros explorados pelos seringalistas sem escrúpulos, observa as situações injustas provocadas por seu Juca" (CRISTÓVÃO, p. 21). O personagem viu todas as discrepâncias nos preços dos produtos vendidos aos seringueiros, o quanto Juca Tristão lucrava sugando as forças trabalhistas. $\mathrm{O}$ português compreendeu a teia do sistema de aviamento que prendia os coletores de borracha por intermináveis anos:

Alberto sentia uma curiosidade dolorosa ao ler toda essa papelada, confrontando algarismos e inventariando o tempo que cada um trabalhava 
a mais em proveito do amo. Depois, chamado pela disparidade das situações, quedava-se absorto sobre as cifras da mesada que Juca enviava à mulher: três contos de réis que significava o preço dos muitos anos que um seringueiro necessitava para o seu resgate. Alberto juntava àquilo as viagens do patrão a Belém, sempre marcadas por grandes quantias recebidas da casa aviadora, as maiores que se viam em todos os lançamentos verificados e ficava mais pensativo ainda. Doíam-Ihe essas descobertas, esses números e contrastes. Poder absoluto, por herança ou outro conceito estabelecido, em prol dum só todos os demais se sacrificavam. Confirmava-se, assim, tudo quanto se dizia sobre a vida dos seringueiros, desde o Pará à Bolívia e do Ceará distante às fronteiras do Peru, onde a sorte dos párias não seria melhor. (CASTRO, 1972, p. 212-213).

Diante da situação difícil, todos os objetivos de riquezas caem por terra e instaura sobre os trabalhadores sentimentos de derrota, como mostra a narração: "mas o tempo decorria e os que, de começo, espalhavam energias acabavam mostrando depauperamentos; os que haviam trazido expressão de futuros vencedores arrastavam-se depois como vencidos" (CASTRO, 1972, p. 159).

Portanto, os sonhos desses aventureiros projetados na Amazônia transfiguravam-se às desilusões. Desse modo, é desmontada a ideia de que a selva seria uma fonte de riqueza. 0 Eldorado é falso. É isso que se pode perceber na fala de Firmino, ao concluir que foi ludibriado: "Aqui não há fortuna" (CASTRO, 1972, p. 124).

\section{CONSIDERAÇÕES FINAIS}

Diante da abordagem desenvolvida, é notável que Ferreira de Castro desconstrói a imagem do Eldorado amazônico. Porém, essa desconfiguração se dá mais pelo viés do "inferno social" do que por meio do tão divulgado "inferno verde", pois os seringueiros viviam no aprisionamento, miséria e degradação. Contudo, isso não diminui o valor da 
narrativa porque ela cumpre o objetivo maior que é o questionamento da imagem de prosperidade infinita.

Tal problematização é construída por meio de um jogo de oposições entre imagens ambivalentes da Amazônia: inicialmente o Eldorado que se transforma em "inferno verde", depois o deslocamento do "inferno" natural para o social. No começo, a narração mostra que os seringueiros vislumbravam a região como fonte de riqueza. No entanto, ao chegar à selva, além dos perigos que ela apresentava, como doenças e ataque de índios e animais, só encontravam miséria e degradação.

Ao fim da narrativa, fica evidente para o leitor que a pobreza extrema e a deterioração humana eram causadas pelas ações de homens que aprisionavam e escravizavam outros homens em benefício próprio. Progressivamente, declina a visão da Amazônia como paraíso e emerge uma imagem de trevas. Assim o texto castriano contribui para olhares diversificados entorno da região.

\section{REFERÊNCIAS}

CASTRO, José Maria Ferreira de. A selva. São Paulo: Verbo Ltda, 1972.

. Arquivo - Pequena história de emigrantes. In: Castriana - estudos sobre Ferreira de Castro e sua geração. Ossela, n. 3, 2007, p. 6-27. Disponível em: <http://www.ceferreiradecastro.org/pdf/castriana3.pdf>. Acesso em: 01 de março de 2018.

CRISTÓVÃO, Fernando. Ferreira de Castro e a literatura brasileira. In: Colóquio Letras Inquérito: o futuro do Português como língua literária em África. Homenagem a Ferreira de Castro. № 21, setembro de 1974, p. 20-22. Disponível em: $<$ http://coloquio.gulbenkian.pt/bib/sirius.exe/issueContentDisplay? $n=21 \& p=20 \& o=r>$.

Acesso em 01 de março de 2018.

CUNHA, Euclides da. À margem da história. São Paulo: Martins Fontes, 1999.

GONÇALVES, Carlos Walter Porto. Amazônia, Amazônias. Segunda edição. São Paulo: Contexto, 2005. 
GUILLEN, Isabel Cristina Martins. Errantes da selva: história da migração nordestina para a Amazônia. Recife: Universitária da UFPE, 2006.

HATOUM, Milton. A natureza como fiç̧ão. In: GROSSMANN, Judith [et. al]. O espaço geográfico no romance brasileiro. Salvador: 1993, (p. 103-117).

LIMA, Lucilene Gomes. Fiç̧ões do ciclo da borracha: A selva, Beiradão e $O$ amante das amazonas. Manaus: Editora da universidade federal do Amazonas, 2009.

PIZARRO, Ana Amazônia-as vozes do rio: imaginário e modernização. Belo Horizonte:Editora UFMG, 2012.

SILVEIRA, Francisco Maciel. A literatura portuguesa em perspectiva. São Paulo: Atlas, 1993.

SOUZA, Márcio. A expressão amazonense - do colonialismo ao neocolonialismo. São Paulo: Alfa-Omega, 1977.

WEINSTEIN, Barbara. A borracha na Amazônia: Expansão e decadência. Tradução: Lólio Lourenço de Oliveira. São Paulo: HUCITEC, 1993.

Artigo recebido em: 31 de maio de 2018. Artigo aprovado em: 28 de agosto de 2018. 